\title{
Research impact and productivity of Benin according to the Science Citation Index Expanded (1973 to 2018)
}

\section{Julián Monge-Nájera ${ }^{1}$, Eustache Mêgnigbêto ${ }^{2} \&$ Yuh-Shan $\mathrm{Ho}^{3 *}$}

1. Universidad Estatal a Distancia, Laboratorio de Ecología Urbana, Vicerrectoría de Investigación, 2050 San José, Costa Rica; julianmonge@gmail.com,jmonge@uned.ac.cr

2. Bureau d'études et de recherches en science de l'information (BERSI), 09 BP 477 Saint Michel, Cotonou, Republic of Benin; eustachem@gmail.com

3. Trend Research Centre, Asia University, No. 500, Lioufeng Road, Wufeng, Taichung 41354, Taiwan; ysho@asia.edu.tw

*Correspondence

Received 26-II-2020. Corrected 01-V-2020. Accepted 10-VI-2020.

\begin{abstract}
Introduction: In Benin, a tropical West African country of 11 million inhabitants where the economy is based on agriculture, the only bibliometric work available has focused on the role of collaboration among researchers, but there are no general long term studies of the country's scientific output. Objective: To analyse the scientific output of Benin, according to the Science Citation Index Expanded, in a 46-year period. Methods: We searched for "Benin" in the country/region field of the index and analysed the results with descriptive statistics. Results: We found 4557 documents, published between 1973 and 2018. They closely match the trends previously found in other small tropical countries: domination of articles over other types of publication like letters and notes; increase in total number of articles published each year; small collaborations in large American and European projects; and a long article lifespan that reflects the relatively slow accumulation of scientific research in tropical regions. Considering the size of the country's economy, Benin has a good level of scientific productivity. Conclusion: In its scientific activity, Benin is similar to other tropical countries, and would benefit from increased cooperation among local researchers; from less dependence on small participations in international megaprojects, and from opening the door to research in areas of innovation rather than just solving immediate problems.
\end{abstract}

Key words: Web of Science Core Collection; tropical country; South Africa; scientific collaboration; scientific productivity; research areas; bibliometrics.

Monge-Nájera, J. Mêgnigbêto, E., \& Ho, Y.S. (2020). Research impact and productivity of Benin according to the Science Citation Index Expanded (1973 to 2018). Revista de Biología Tropical, 68(3), 909-918.

There are few general studies of the scientific production of African countries (Nwagwu, 2006; Adams, King, \& Hook, 2010), but generally, historical analyses conclude that local scientific output before 1960 was small. There were improvements in the 1970s, but unfortunately, a political and economic deterioration in several African countries in the 1980 s led foreign donors to recommend that research funds be limited to a few successful research institutions that seemed to better take advantage of financial support (Davis, 1983; Gaillard, 1992). Throughout Africa, like everywhere else in the world, political changes affect significantly the funds available for universities. Most of the research and the policy normally is to gear those funds towards economic development (Amankwah-Amoah, 2016), a typically "Third World" approach that limits innovation. 
According to several studies, South Africa and Egypt produced most of the African scientific papers in the 1990s. Research was focused on clinical medicine, biology and chemistry, while international collaboration was done mostly with the USA and France but normally with those countries playing the leading roles in the projects (Narváez-Berthelemot, Russel, Arvanitis, Waast, \& Gaillard, 2002). Also, at that time, basic science declined, agricultural and medical sciences stagnated and only engineering grew (Arvanitis et al., 2000). In the next decade South Africa entered a new age in science where researchers received better funding and increased their per capita production, collaborated more, and published in larger journals (Pouris \& Pouris, 2009; Kahn, 2011; Toivanen \& Ponomariov, 2011; Pouris, 2012). In the 2000s, South Africa produced $79 \%$ of African scientific publications (Pouris, 2010). An important finding from this period is that South African journals had a distinctive citation impact on international research communities, but this impact was not reflected in the Science Citation Index (normal or expanded) because these journals were not included in the index at all (Tijssen, 2007).

The decade that started in 2010 has been better regarding which countries produce the most papers, and the role of collaboration inside and outside each country. In the current decade, most research was published by four countries, one in the South and three in the north of the continent: South Africa, Egypt, Tunisia, Nigeria and Algeria (Sooryamoorthy, 2018). This is confirmed by a report that the most productive research institutions are four universities in South Africa and one in Egypt, namely the universities of Cape Town, Stellenbosch, Witwatersrand, Pretoria, and Ain Shams (Lateef, Ogunkunle, \& Adigun, 2016).

In the present decade also happened an increase in collaboration with American and European researchers, who are better funded and have access to journals included in the Science Citation Index (Tijssen, 2007; Onyancha,
2011; Landini, Malerba, \& Mavilia, 2015; Thelwall, 2017); and thus are reflected in this article. As a result of this growth in productivity the number of African scientific papers is growing faster than the world average, but it still represents less than $1.5 \%$ of the world's total, even though Africa has $17 \%$ of the world's population (Confraria \& Godinho, 2015). There are also other aspects to consider: first, most citations in African journals are not covered by the Science Citation Index Expanded and thus are not covered by our study; second, medical and natural science research receive disproportionate attention (Pouris, \& Ho, 2014) and, third, African research still depends too much on the funds of foreign partners (Mêgnigbêto, 2013).

In the case of Benin, a tropical West African country of around 11 million inhabitants where the economy is still based on agriculture, most bibliometric work has dealt with the role of collaboration among local and international scientists. Benin's collaboration with other African countries, like Ghana, is increasing (Owusu-Nimo \& Boshoff, 2017). Far more national and international collaboration is needed (Jiggins et al., 2016), because collaboration is currently dominated by long tenure authors who only collaborate among themselves. Collaborations should be more open with young researchers who are starting their careers (Azondekon, 2018; Azondekon, Harper, Agossa, Welzig, \& McRoy, 2018).

As the economy grows, Benin is increasing its carbon footprint and having more impact on the wellbeing of local societies and ecosystems (van Vuuren \& Smeets, 2000). Thus, Benin needs to adapt its science to the changing economy and climate of this decade (Jiggins et al., 2016). Here we use descriptive statistics to analyse the scientific output of Benin that was included the Science Citation Index Expanded during a 46 year period, with emphasis on what is studied, who does the research and what impact it has in the journals covered by the index. 


\section{MATERIALS AND METHODS}

We used the Science Citation Index Expanded, from the Web of Science Core Collection in Clarivate Analytics. We searched for documents with the word "Benin" in the country/region field using the advanced search. We found 4557 documents, published between 1973 and 2018 (updated date: November 05, 2019). Affiliations from England, Scotland, Northern Ireland, Wales, and Cayman Islands were reclassified as being from the UK (United Kingdom) (Chiu \& Ho, 2005). Affiliations from Macao before 1999 were reclassified as being from China. Affiliations from New Caledonia, French Guiana, and Fr Polynesia (French Polynesia) were reclassified as being from France (Monge-Nájera \& Ho, 2015). Affiliations from Rep Congo (Republic of the Congo) were reclassified as being from Congo (Republic of Congo) (Tchuifon Tchuifon et al., 2017). Affiliations from Zaire were reclassified as being from Dem Rep Congo (Democratic Republic of the Congo) (Pouris \& Ho, 2014). Affiliations from Greenland were reclassified as being from Denmark (Tchuifon Tchuifon, Fu \& Ho, 2017). Affiliations from Neth Antilles (Netherlands Antilles) were reclassified as being from Netherlands. Affiliations from United Arab and United Ara were reclassified as being from U Arab Emirates (United Arab Emirates). Affiliations from Fed Rep Ger (Federal Republic of Germany) were reclassified as being from Germany (Ho, 2012). Affiliations from Palestinian Ter (Palestinian territories) were reclassified as being from Palestine.

Web of Science Core Collection citations can change over time and cannot be easily compared; to solve this limitation, Ho's group proposed a new indicator, $T C_{\text {year }}$ (Chuang et al., 2011; Wang, $\mathrm{Fu}, \& \mathrm{Ho}, 2011)$, i.e. total citations from Web of Science Core Collection since publication to the end of the most recent year (or last year), for example 2018 in this study $\left(T C_{2018}\right)$. Citations per publication $\left(C P P_{2018}\right)$ is $T C_{2018}$ /number of publications $(T P)$ (Ho \& Ho, 2015). In addition, $C_{2018}$, the total citations only in 2018, was also applied (Ho, 2012). The advantage of using $T C_{\text {year }}, C_{\text {year }}$, and $C P P_{\text {year }}$ is that they are invariable and ensure repeatability compared with the index of citation from the Web of Science Core Collection (Fu, Wang, \& Ho, 2012). It was also pointed out that it is not appropriate to use a single indicator to evaluate the impact of an article (Ho \& Hartley, 2016). Researchers should pay more attention to the top articles with $C_{\text {year }}$ but not to those with $T C_{\text {year }}$ only, because some highly cited articles with $T C_{\text {year }}$ have not had a high impact in recent years (Ho \& Hartley, 2016). In 2017, a particular analysis among document types, their citations per publication $\left(C P P_{\text {year }}=T C_{\text {year }} / T P\right)$. Number of authors per publication $(A P P=A U /$ $T P)$ was proposed by Monge-Nájera and Ho (2017b) and we follow it here.

Additional figures and tables (not presented in the main text of this article) appear in Appendix 1, which can be downloaded from the journal site and also here.

\section{RESULTS}

Document types and their citation: The great majority of documents are articles, followed by meeting abstracts and reviews (Table 1). About authorship, notes are co-authored by a mean of four researchers, while other types of publication, like articles and review articles, have larger numbers of co-authors (Table 1). Overall, Benin publications have accumulated 71384 citations that have been recorded in the index (Table 1, citations in journals not included in the index are not counted). Book chapters are the most cited type of document (with a mean of 76 citations per book chapter) followed by review articles (27 citations) and normal articles (17 citations, Table 1).

Total output of articles, and their citations, over time: The yearly number of articles reaching the index increased from 53 in the year 2001 to over 364 in 2018. The count of citations per publication went from 10 in 1977 to around 35 in 2002. It fell to around 10 in 2013 and started to increase afterwards. The 
TABLE 1

Citations and authors in Benin according to document type from 1973 to 2018

\begin{tabular}{lcccc}
\multicolumn{1}{c}{ Document type } & $T P$ & $A P P$ & $T C_{2018}$ & $C P P_{2018}$ \\
Article & 3870 & 15 & 66967 & 17 \\
Meeting abstract & 392 & 7.2 & 29 & 0.074 \\
Review & 135 & 12 & 3606 & 27 \\
Letter & 66 & 4.7 & 326 & 4.9 \\
Proceedings paper & 55 & 5.5 & 764 & 14 \\
Editorial material & 51 & 5.2 & 312 & 6.1 \\
Correction & 16 & 17 & 39 & 2.4 \\
News item & 14 & 7.4 & 49 & 3.5 \\
Note & 10 & 3.7 & 56 & 5.6 \\
Biographical-item & 3 & 16 & 0 & 0 \\
Book chapter & 2 & 4.0 & 152 & 76 \\
Data paper & 2 & 10 & 3 & 1.5 \\
\hline
\end{tabular}

$T P$ : number of articles; $A P P$ : number of authors per publication $(A U / T P) ; T C_{2018}$ : total citations since publication to the end of 2018; $C P P_{2018}$ citations per paper $\left(T C_{2018} / T P\right)$.

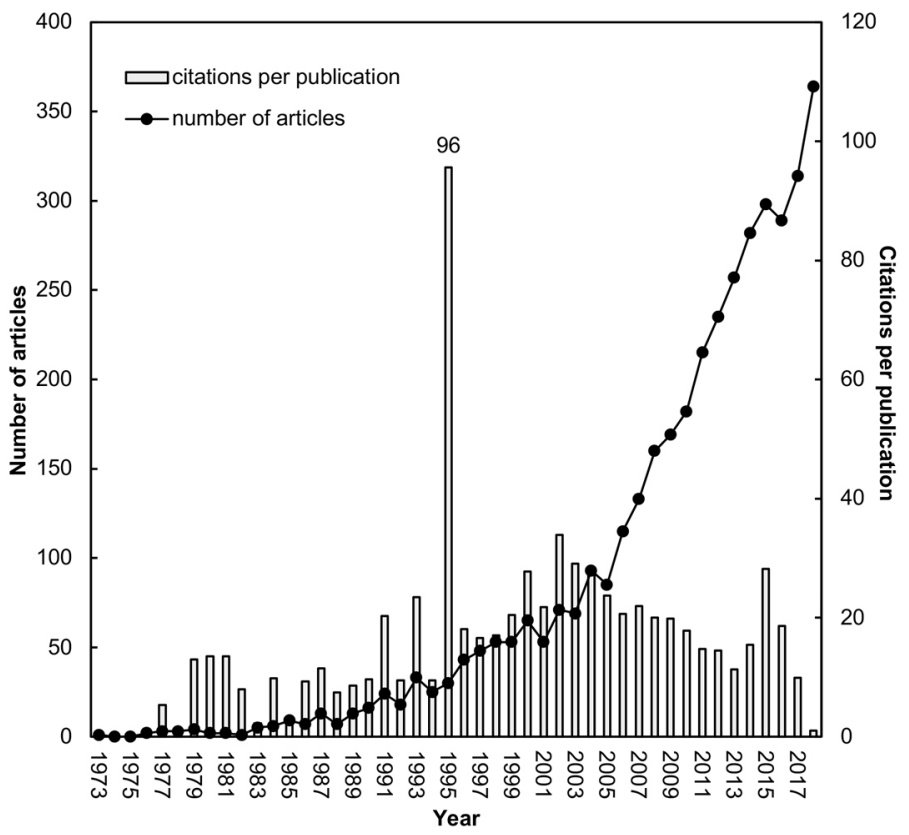

Fig. 1. Trends of Benin articles and citations per publication from 1973 to 2018.

outlier was an article that produced 96 citations in 1995 (Fig. 1).

Article lifespan: Most citations occur around the second and third year of publication, then steadily fall over the following years. Benin articles have a long citation life, some papers are still being cited almost 40 years after their publication (Appendix 1: Fig. 1).

Top cited authors: The most cited Benin authors in the SCIExpanded are all from the Université d'Abomey-Calavi. They are: Achille Massougbodji, an expert in paludism at 
the Centre d'Etude et de Recherche sur le Paludisme Associé à la Grossesse et à l'Enfance; Brice Augustin Sinsin, ecologist at the Faculté des Sciences Agronomiques; Martin Akogbeto, a malary expert at the Department of Zoology and Genetics, Mahouton Norbert Hounkonnou, a mathematician; and Achille Ephrem Assogbadjo, Forester at the Laboratory of Applied Ecology (Digital Appendix 1: Table 1). For top cited authors who published before the 2003, citations grew and fell in a soft curve. For those who published after the year 2014, the growth in citations is fast, but the most also show a rapid fall in the number of citations in recent years, suggesting a more rapid cycle and a shorter lifespan of citations for recent work (Appendix 1: Fig. 2).

Top cited articles: All top cited articles are small collaborations by Benin scientists in international megaprojects lead by foreign scientists and based on industrialized countries. These megaprojects deal mostly with health problems of international interest, like overall causes of death in the human population; human papillomavirus and cancer; disabilities and life expectancy; a gel to prevent the transmission of the AIDS virus; and, on a very different subject related to agriculture and food production, the biogeography of soil fungi (Appendix 1: Table 2).

Top productive journals: The top productive journals were PLoS One, Malaria Journal, Parasites \& Vectors, PLoS Neglected Tropical Diseases, Genetic Resources, and Crop Evolution. All of them are foreign journals that are typically covered by the Science Citation Index because they deal with practical subjects and are based in the USA or Europe (Appendix 1: Table 3).

Citation of local versus collaborative articles: Benin independent papers, i.e. those that were produced by Benin researchers without participation of foreign researchers or institutions, have a mean of 6.7 citations.
International collaborative papers have a mean of 19 citations, i.e. 2.8 times more (Fig. 2).

Collaborative articles over time: The number of international collaborative articles started growing rapidly after the year 2000, and the growth continues to the present. There is a particular strength for collaboration with France and the USA (Appendix 1: Fig. 3).

\section{Publications by country of collabora-} tion: Most collaboration was done with France, Belgium, USA, United Kingdom and Germany. Benin addresses dominate as first or corresponding author. Most total citations are for studies done with African, European and American countries, namely Tanzania, Brazil, Italy, Canada and Kenya (Appendix 1: Table 4).

Publication according to journal subject: Most studies dealt with applied branches of biology, and published in journals specializing in environmental sciences. It is followed by plant sciences, health, zoology and ecology (Fig. 3). According with the journal specialties, most studies were in the fields of tropical medicine, entomology, agronomy, infectious diseases and plant sciences (Appendix 1: Table 5).

\section{DISCUSSION}

Our results from Benin closely match the trends previously found in other small tropical countries: articles dominate numerically, but reviews and books receive more citations. The apparent reason for the abundance of articles is that their structure and length match the most frequent type of research done, which is unfit for other options like letter and short notes. The higher citation rates of reviews and book chapters reflects the fact that reviews and books summarize large amounts of information from many articles. Thus, reviews and book chapters are more likely to be cited when an author wants to reflect what is known about a particular subject (Monge-Nájera \& Ho, 2016; 2017a; 2017b; 2017c; 2018; Ho, Lim, \& Monge-Nájera, 2018) 


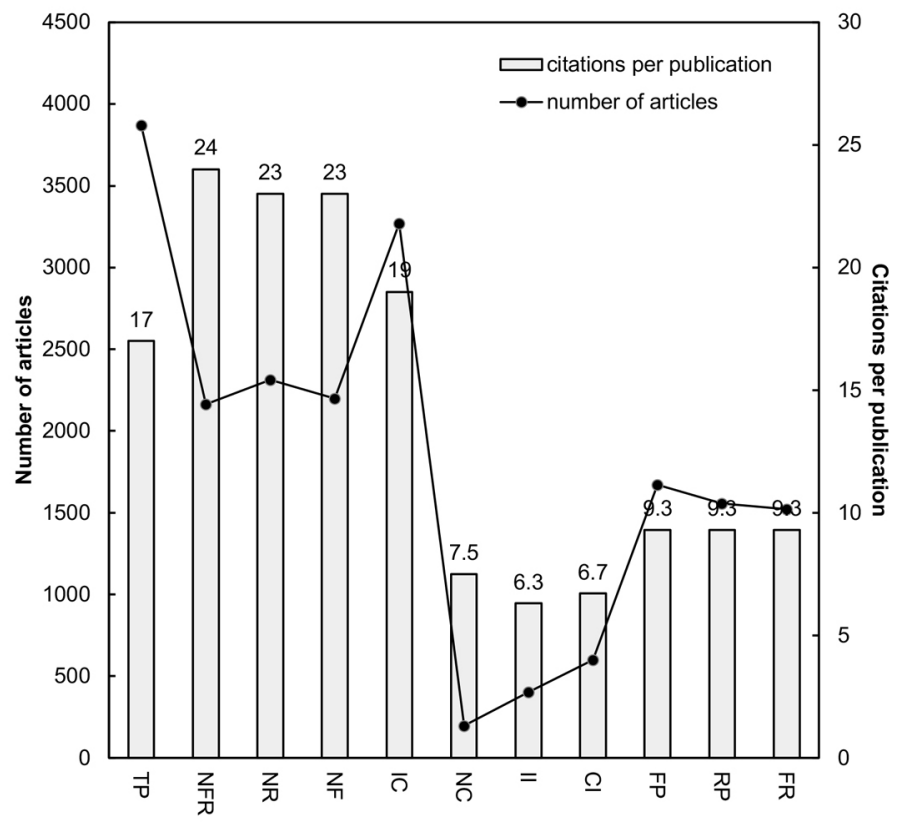

Fig. 2. Citations per publication and number of articles by type of collaboration and authorship. TP: total articles; NFR: both first and corresponding-authors are not from Benin; $N R$ : corresponding-author is not from Benin; $N F$ : first-author is not from Benin; $I C$ : internationally collaborative publications; $N C$ : nationally collaborative publications; $I I$ : institutional independent publications; $C I$ : Benin independent publications; FP: first-author is from Benin; RP: corresponding-author is from Benin; FR: both first and corresponding-authors are from Benin.

The relatively high citation rate that we found for publications with Benin authors can be explained by their participation in well financed international health-related projects, which in turn are frequently cited in the American and European journals that make most of the SCIExpanded database (Tijssen, 2007). The increase in total publications also follows the world trend of a growing number of papers published each year, a trend that is stronger in Africa in general (Confraria \& Godinho, 2015). The fact that most citations take place only after the SCIExpanded stops counting citations, shows that the system is unfair with journals outside of the USA and Europe (Tijssen, 2007; Monge-Nájera, 2014; Monge-Nájera \& Ho, 2016; 2017b; 2018).

The slow curve of citations follows the normal lifespan of articles. The long lifespan of some articles probably reflects the slow pace of growth in the knowledge about nature that is typical of tropical articles (Monge-Nájera \& Ho, 2017a; 2017c; Ho, Lim, \& Monge-Nájera, 2018). The stronger growth of citations in later years may reflect both the historical growth of science in general, and the increased participation in big budget projects (Kahn, 2011).

The existence of a core group of highly successful authors in the Université d'AbomeyCalavi, Benin, is similar to results found in other African studies, in which research of high visibility concentrates in a few laboratories and institutions (Nwagwu, 2006; Mêgnigbêto, 2013; Lateef et al., 2016). The same applies to research subjects and journals (those of medical and economic importance have more publications and thus more citations, not because of a difference in quality, but because there is more work done in those applied fields; Kahn, 2011). Also applies to the fact that participating in large international health projects, centred in industrialized countries, gives authors a large 


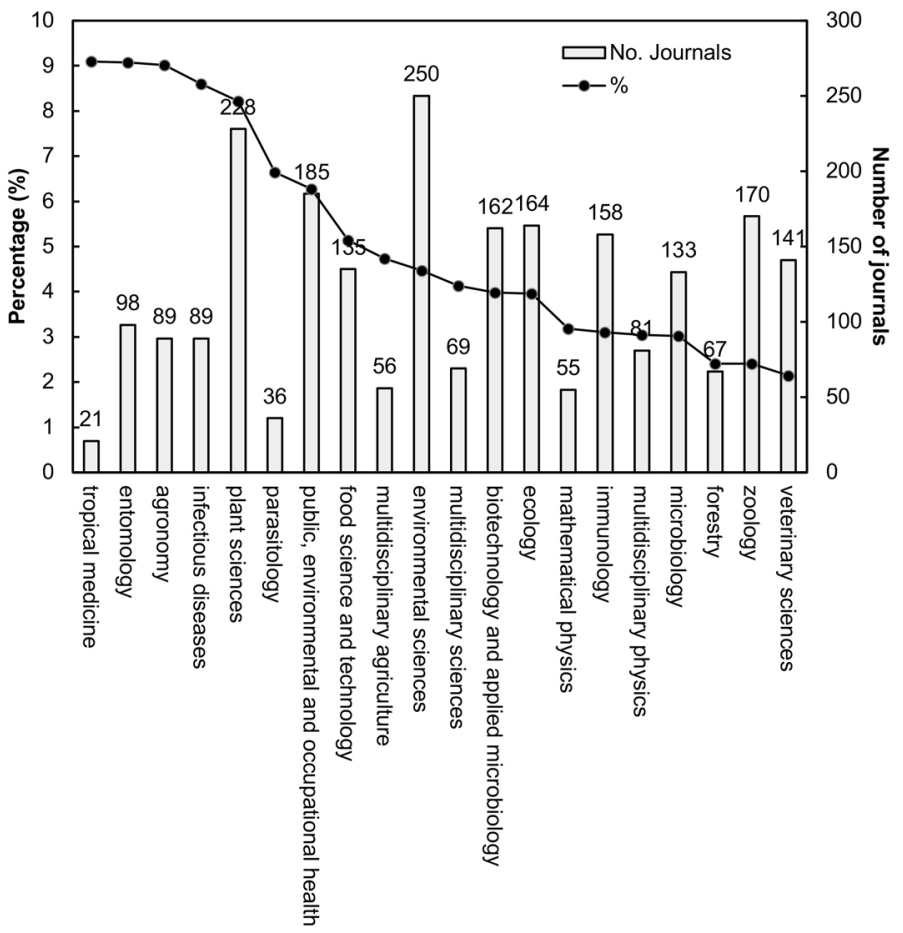

Fig. 3. Percentage of Benin publications and number of journals in each Web of Science category.

visibility and impact, independently of how significant their particular contribution to the project was (Narváez-Berthelemot et al., 2002; Mêgnigbêto, 2013; Landini, Malerba, \& Mavilia, 2015). The nature of international collaboration also fits the general trend that has been found previously for tropical countries; i.e. the powerful research apparatus of the USA makes it an important partner almost everywhere in the world. Ex colonies also collaborate with the colonial power and with geographically close countries (Narváez-Berthelemot et al., 2002; Onyancha, 2011; Pouris \& Ho, 2014).

The higher productivity and citation in applied scientific and technological fields, over those in the social sciences, also fits the known pattern for the tropics and for the world (Narváez- et al., 2002; Pouris, 2010; Mêgnigbêto, 2013). Thus, reflecting the fact that more funds are assigned to research in the "hard sciences". Overall, the scientific productivity and impact of Benin scientists are good considering the size of the country's economy, and local scientists should be commended for this. On the other hand, science in Benin would benefit from increased cooperation among themselves. Benin needs to vary from less dependence on small participations in international megaprojects to open the door to research in areas of innovation that can pay good dividends in the long term. Additionally, to the current research that focuses on solving immediate problems, which is important but less likely to produce significant advances in human knowledge.

Ethical statement: authors declare that they all agree with this publication and made significant contributions; that there is no conflict of interest of any kind; and that we followed all pertinent ethical and legal procedures and requirements. All financial sources are fully and clearly stated in the acknowledgements section. A signed document has been filed in the journal archives. 


\section{RESUMEN}

Impacto y productividad de la investigación hecha en Benin según el Science Citation Index Expanded (1973 a 2018). Introducción: Benín es un país tropical de África occidental con 11 millones de habitantes y una economía basada en la agricultura. Los únicos estudios disponibles sobre su producción se han enfocado en el papel que juega la colaboración entre investigadores, y no hay estudios previos de enfoque amplio y larga duración sobre la producción científica del país. Objetivo: Analizar la producción científica de Benín incluida en el Science Citation Index Expanded en un período de 45 años. Métodos: Buscamos con la palabra "Benin" en el campo de país/región en búsqueda avanzada del índice y los analizamos con estadísticas descriptivas. Resultados: Encontramos 4557 documentos, publicados entre 1973 y 2018 (consulta: 5 nov. 2019). Benín coincide estrechamente con las tendencias encontradas en otros países tropicales pequeños: los artículos son el principal tipo de publicación; hay un aumento en el total de publicaciones; se disfruta de colaboración internacional bien financiada; y los artículos tienen una larga vida útil, que refleja el lento ritmo de crecimiento en el conocimiento de la naturaleza tropical. La existencia de un grupo central de autores de gran éxito (en este caso en la Universidad de Abomey-Calavi) es similar a lo que se da en otros países africanos. Conclusión: Los científicos de Benín tienen una producción respetable, considerando el tamaño de la economía del país. Este país se beneficiaría de una mayor cooperación entre los investigadores locales, de una menor dependencia de pequeñas participaciones en megaproyectos internacionales, y de abrir la puerta a la investigación en áreas de innovación que pueden generar buenos dividendos a largo plazo, además de la investigación actual que solo se enfoca en resolver problemas inmediatos.

Palabras clave: Web of Science; país tropical; África; colaboración científica; productividad científica; áreas de investigación.

\section{REFERENCES}

Adams, J., King, C., \& Hook, D. (2010). Global research report, Africa 2010. Leeds, United Kingdom: Evidence Thomson Reuters.

Amankwah-Amoah, J. (2016). The evolution of science, technology and innovation policies: A review of the Ghanaian experience. Technological Forecasting and Social Change, 110, 134-142. DOI: 10.1016/j. techfore.2015.11.022

Arvanitis, R., Waast, R., \& Gaillard, J. (2000). Science in Africa: A bibliometric panorama using PASCAL database. Scientometrics, 47, 457-473. DOI: 10.1023/A:1005615816165
Azondekon, G.R. (2018). Network Analysis of Scientific Collaboration and Co-authorship of the Trifecta of Malaria, Tuberculosis and HIVIAIDS in Benin (Doctoral dissertation). The University of Wisconsin, Milwaukee, USA.

Azondekon, R., Harper, Z.J., Agossa, F.R., Welzig, C.M., \& McRoy, S. (2018). Scientific authorship and collaboration network analysis on malaria research in Benin: papers indexed in the web of science (19962016). Global Health Research and Policy, 3(1), 11. DOI: $10.1186 / \mathrm{s} 41256-018-0067-\mathrm{x}$

Chiu, W.T., \& Ho, Y.S. (2005). Bibliometric analysis of homeopathy research during the period of 1991 to 2003. Scientometrics, 63(1), 3-23. DOI: 10.1007/ s11192-005-0201-7

Chuang, K.Y., Wang, M.H., \& Ho, Y.S. (2011). Highimpact papers presented in the subject category of water resources in the Essential Science Indicators database of the Institute for Scientific Information. Scientometrics, 87(3), 551-562. DOI: 10.1007/ s11192-011-0365-2

Confraria, H., \& Godinho, M.M. (2015). The impact of African science: A bibliometric analysis. Scientometrics, 102, 1241-1268. DOI: 10.1007/s11192-014-1463-8

Davis, C.H. (1983). Institutional sectors of 'mainstream' science production in sub-Saharan Africa, 19701979: A quantitative analysis. Scientometrics, 5, 163175. DOI: $10.1007 / \mathrm{BF} 02095626$

Fu, H.Z., Wang, M.H., \& Ho, Y.S. (2012). The most frequently cited adsorption research articles in the Science Citation Index (Expanded). Journal of Colloid and Interface Science, 379(1), 148-156. DOI: 10.1016/j.jcis.2012.04.051

Gaillard, J. (1992). Science policies and cooperation in Africa: Trends in the production and utilization of knowledge. Science Communication, 14, 212-233. DOI: $10.1177 / 107554709201400212$

Ho, H.C., \& Ho, Y.S. (2015). Publications in dance field in Arts \& Humanities Citation Index: A bibliometric analysis. Scientometrics, 105(2), 1031-1040. DOI: 10.1007/s11192-015-1716-1

Ho, Y.S. (2012). Top-cited articles in chemical engineering in Science Citation Index Expanded: A bibliometric analysis. Chinese Journal of Chemical Engineering, 20(3), 478-488. DOI: 10.1016/ S1004-9541(11)60209-7

Ho, Y.S., \& Hartley, J. (2016). Classic articles published by American scientists (1900-2014): A bibliometric analysis. Current Science, 111(7), 1156-1165. DOI: $10.18520 / \mathrm{cs} / \mathrm{v} 111 / \mathrm{i} 7 / 1156-1165$

Ho, Y.S., Biaw Leng Lim, L., \& Monge-Nájera, J. (2018). Benin publications in the Science Citation Index Expanded (1973-2016): bibliometrics and 
comparison with other tropical countries. Revista de Biología Tropical, 66(3), 1090-1100. DOI: 10.15517/ rbt.v66i3.31714

Jiggins, J., Essegbey, G., Klerkx, L.W.A., van Paassen, A., Pyburn, R., \& Tossou, R. (2016). The uses of research: action researching in and across nine agroenterprise domains: the experience of the convergence of sciences-strengthening innovation systems programme in Benin, Ghana and Mali. In F.J. Mytelka, L. van Huis, A. Röling, \& N. Wageningen (Eds.), Innovation systems (pp. 101-123). Wageningen, The Netherlands: The Technical Centre for Agricultural and Rural Cooperation (CTA).

Kahn, M. (2011). A bibliometric analysis of South Africa's scientific outputs: Some trends and implications. South African Journal of Science, 107, 1-6. DOI: 10.4102/sajs.v107i1/2.406

Landini, F., Malerba, F., \& Mavilia, R. (2015). The structure and dynamics of networks of scientific collaborations in Northern Africa. Scientometrics, 105(3), 1787-1807. DOI: $10.1007 / \mathrm{s} 11192-015-1635-1$

Lateef, A., Ogunkunle, A.T.J., \& Adigun, G.O. (2016). Google scholar citation in retrospect: Visibility and contributions of African scholars. Journal of Scientometrics and Information Management, 10(2), 219236. DOI: 10.1080/09737766.2016.1213966

Mêgnigbêto, E. (2013). Scientific publishing in West Africa: Comparing Benin with Ghana and Senegal. Scientometrics, 95, 1113-1139. DOI: 10.1007/ s11192-012-0948-6

Monge-Nájera, J. (2014). La invalidez del Factor de Impacto como indicador del impacto de las revistas científicas latinoamericanas. Revista de Biología Tropical, 62(1), 407-41. DOI: 10.15517/rbt.v62i1.13540

Monge-Nájera, J., \& Ho, Y.S. (2015). Bibliometry of Panama publications in the Science Citation Index Expanded: Publication type, language, fields, authors and institutions. Revista de Biología Tropical, 63(4), 1255-1266. DOI: 10.15517/rbt.v63i4.21112

Monge-Nájera, J., \& Ho, Y.S. (2016). Bibliometry of the Revista de Biología Tropical / International Journal of Tropical Biology and Conservation: document types, languages, countries, institutions, citations and article lifespan. Revista de Biología Tropical, 64(3), 1223-1235. DOI: 10.15517/rbt.v64i3.22142

Monge-Nájera, J., \& Ho, Y.S. (2017a). Bibliometrics of Nicaraguan publications in the Science Citation Index Expanded. Revista de Biología Tropical, 65(2), 643-655. DOI: 10.15517/rbt.v65i2.23985

Monge-Nájera, J., \& Ho, Y.S. (2017b). El Salvador publications in the Science Citation Index Expanded: subjects, authorship, collaboration and citation patterns. Revista de Biología Tropical, 65(4), 1428-1436. DOI: 10.15517/rbt.v65i4.28397
Monge-Nájera, J., \& Ho, Y.S. (2017c). Honduras publications in the Science Citation Index Expanded: institutions, fields and authors. Revista de Biología Tropical, 65(2), 657-668. DOI: 10.15517/rbt. v65i2.25893

Monge-Nájera, J., \& Ho, Y.S. (2018). Guatemala articles in the Science Citation Index Expanded: bibliometry of subjects, collaboration, institutions and authors. Revista de Biología Tropical, 66(1), 312-320. DOI: 10.15517/rbt.v66i1.29875

Narváez-Berthelemot, N., Russel, J.M., Arvanitis, R., Waast, R., \& Gaillard, J. (2002). Science in Africa: An overview of mainstream scientific output. Scientometrics, 54, 229-241. DOI: 10.1023/A:1016033528117

Nwagwu, W. (2006). A bibliometric analysis of productivity patterns of biomedical authors of Nigeria during 1967-2002. Scientometrics, 69(2), 259-269. DOI: 10.1007/s11192-006-0152-7

Onyancha, O.B. (2011). Research collaborations between South Africa and other countries, 1986-2005: An informetric analysis. African Journal of Library and Information Science, 21(2), 99-112.

Owusu-Nimo, F., \& Boshoff, N. (2017). Research collaboration in Ghana: Patterns, motives and roles. Scientometrics, 110(3), 1099-1121. DOI: 10.1007/ s11192-016-2221-x

Pouris, A. (2010). A scientometric assessment of the Southern Africa Development community: Science in the tip of Africa. Scientometrics, 85, 145-154. DOI: 10.1007/s11192-010-0260-2

Pouris, A. (2012). Science in South Africa: The dawn of a renaissance? South African Journal of Science, 108 1-6. DOI: $10.4102 /$ sajs.v108i7/8.1018

Pouris, A., \& Ho, Y. S. (2014). Research emphasis and collaboration in Africa. Scientometrics, 98(3), 21692184. DOI: $10.1007 / \mathrm{s} 11192-013-1156-8$

Pouris, A., \& Pouris, A. (2009). The state of science and technology in Africa (2000-2004): A scientometric assessment. Scientometrics, 79, 297-309. DOI: 10.1007/s11192-009-0419-x

Sooryamoorthy, R. (2018). The production of science in Africa: an analysis of publications in the science disciplines, 2000-2015. Scientometrics, 115(1), 317-349. DOI: $10.1007 / \mathrm{s} 11192-018-2675-0$

Tchuifon Tchuifon, D.R., Fu, H.Z., \& Ho, Y.S. (2017), Cameroon publications in the Science Citation Index Expanded: Bibliometric analysis. Revista de Biología Tropical, 65(4), 1582-1591. DOI: 10.15517/rbt. v65i4.27101

Thelwall, M. (2017). Trend of African Scientific Output and Impact 1996-2015. African Journal of Library, Archives \& Information Science, 27(2), 131-143. 
Tijssen, R.J.W. (2007). Africa's contribution to the worldwide research literature: New analytical perspectives, trends, and performance indicators. Scientometrics, 71, 303-327. DOI: 10.1007/s11192-007-1658-3

Toivanen, H., \& Ponomariov, B. (2011). African regional innovation systems: Bibliometric analysis of research collaboration patterns 2005-2009. Scientometrics, 88 , 471-493. DOI: 10.1007/s11192-011-0390-1 van Vuuren, D.P., \& Smeets, E.M.W. (2000). Ecological footprints of Benin, Bhutan, Costa Rica and the Netherlands. Ecological Economics, 34(1), 115-130. DOI: 10.1016/S0921-8009(00)00155-5

Wang, M.H., Fu, H.Z., \& Ho, Y.S. (2011). Comparison of universities' scientific performance using bibliometric indicators. Malaysian Journal of Library \& Information Science, 16(2), 1-19. 